Review of: Mabel Berezin (2009), "Illiberal Politics in Neoliberal Times: Culture, Security and Populism in the New Europe", New York: Cambridge University Press

\author{
Bornschier, Simon
}

DOI: https://doi.org/10.1017/S1537592712002927

Posted at the Zurich Open Repository and Archive, University of Zurich

ZORA URL: https://doi.org/10.5167/uzh-86486

Journal Article

Accepted Version

Originally published at:

Bornschier, Simon (2013). Review of: Mabel Berezin (2009), "Illiberal Politics in Neoliberal Times: Culture, Security and Populism in the New Europe", New York: Cambridge University Press. Perspectives on Politics, 11(1):229-231.

DOI: https://doi.org/10.1017/S1537592712002927 


\section{Illiberal Politics in Neoliberal Times. Culture, Security and Populism in the New}

Europe. By Mabel Berezin. New York: Cambridge University Press, 2009. 304p. \$99.00 cloth, \$ 37.99 paper.

Simon Bornschier, University of Zurich

Illiberal Politics in Neoliberal Times tackles the paradoxical revival of nationalism in an age in which national boundaries are lowered in the process of European integration. Most of the book analyzes one particular case, that of France, and offers a new interpretation of the rise of the Front National. In analyzing the party's origins, Berezin first reminds us of the significant role of anti-communism and the rejection of 1968 in the Front National's early discourse. This is important because the rise of the extreme populist right all too often is analyzed only in terms of the salience of the immigration issue. Immigration indeed became important in the 1980s and early 1990s. Increasingly, however, Berezin argues, Europe has replaced it as the main issue driving support for the extreme populist right, and this shift has substantially widened the party's appeal.

To substantiate her argument, Berezin centers her analysis on the Front National's discourse and the broader context in which the party became one of the most successful of its type in Europe. This perspective allows her to make the provocative, but largely convincing claim that the Front National's setback in the 2007 presidential elections, rather than revealing the short-term anti-establishment nature of right-wing populist mobilization, was actually a paradox of success: The Front National had transformed the discourse in French political society, which contributed to bringing Nicolas Sarkozy to the presidency with a toned-down version of the populist right's discourse.

To systematize the analysis, the trajectory of the Front National and its impact on French society are divided into five time periods. The first phase is "ascendance", where the extreme right's first electoral showings were met with protest by organizations such as SOS racisme. While the left governs France, the party's heritage as a countermovement against communism and 1968 is still very visible. The next phase, "mobilization", spans from 1995 to 1997. While the Gaullists govern and implement neoliberal reforms, the Front National manages to broaden its support. "Banalisation" is characterized by success and defeat. Jean-Marie Le Pen's speeches increasingly come to 
focus on European integration. But the party's split in 1999 gives pause to its rise. Le Pen's spectacular comeback in the 2002 presidential elections, which marks the end of the fourth phase ("climbing back", 2000-2002), came as a surprise to many. Ultimately, in the last phase, "Dédiabolisation", the Front National comes very close to representing ideas that by now have become mainstream. It is not so much that the Front National has become mainstream. Rather, the mainstream increasingly comes to resemble the Front National.

In methodological terms, events "that marked turning points in collective national perceptions" (p. 11) form the unit of analysis. Events are deemed important because they condition what happens later in a path-dependent manner. As stated further back in the book, they "serve as templates of possibilities and sites of collective evaluation. [They] may alter collective national perceptions as well as generate powerful emotions (...)" (p. 199). The "events" studied in the book include the party's initial breakthrough in the early 1980s, the Strasbourg convention that defined the party as "Neither Right Nor Left: French", the 2002 presidential elections, when Le Pen came in second, as well as the French "No" to the EU constitution in 2005.

Although perhaps not as radical a departure from prior treatments of the Front National as suggested in Chapter 2, particularly not from the French literature, the author's culturalist approach illuminates several phenomena that many studies have missed. One example is the Front National's appropriation of Labor Day as a nationalist holiday (Chapter 5). The book thereby contributes to our understanding of how the extreme right succeeded in rallying the working class throughout Western Europe, an empirical fact lacking a convincing explanation. By showing how the Front National attacks neoliberalism, Berezin also corrects the market liberal image sometimes attributed to the populist right. Second, Berezin's analysis of events reveals the Front National's surprisingly strong emphasis on the challenge to national sovereignty posed by European integration and the larger process of globalization since the late 1990s. Because Europe has rarely been an important issue in election campaigns, it has tended to be discarded as one of the extreme right's prime issues - a mistake, it seems. Election campaigns are special events, where challenging parties are at the mercy of the major players in the party system in shaping the terms of the debate.

In terms of cross-national differences, Berezin argues that the challenge posed by European integration and globalization differs depending on what she calls 
"consolidation regimes" (pp. 49-54). This term describes the relationship between national culture and the polity, or between the nation and the state. Hegemonic consolidation regimes are characterized by a strong state (which mainly denotes an institutionalized parliamentary democracy, and thus does not vary across advanced industrial countries) and a nationalized culture. This type, exemplified by France, is vulnerable to external threats. Flexible consolidation regimes, one of the other two possible types, are internally less coherent, but "externally more flexible and much more able than hegemonic consolidation regimes to respond to external threats or exogenous factors" (p. 51). In the last chapter before the conclusion, France is contrasted to the Italian case, an example of a country with a flexible consolidation regime. It is only here that this part of the analytical framework really becomes relevant. Indeed, all components of the Italian right share a firm commitment to Europe, and Europe is seen as an opportunity, rather than a threat. But it seems difficult to attribute the differences in the divisiveness of Europe exclusively to France's cultural monism as opposed to Italy's cultural pluralism. Berezin herself highlights how the mainstreaming of the Alleanza Nazionale was shaped by the breakdown of the first Italian republic's party system.

While the book is stimulating, it would have benefited from a stronger engagement with the literature on the extreme right and the transformation of West European party systems. The wholesale rejection of existing research based on a rather cursory discussion on five pages (pp. 40-45) is unsatisfactory. Indeed, the depiction of the Front National's early profile seems rather well compatible with Piero Ignazi's influential claim that the extreme populist right represents a "silent counter-revolution" against parties mobilizing on post-materialist values. For Berezin, however, post-materialism only explains the instability of partisan alignments, not the formation of new divides that may be related to the extreme populist right's mobilization, and that can result in new alignments. It seems unfortunate that the works of Herbert Kitschelt, Hans-Georg Betz and Piero Ignazi are unduly reduced to political economy explanations. Berezin thereby neglects accounts that analyze the extreme right in terms of the party system dynamics of the past three decades. Consequently, Berezin assumes that the "reassertion of the nation" (p. 218) encompasses all segments of French public, when we know that the electorate of the New Left is staunchly cosmopolitan (though possibly anti-market). Despite these minor criticisms, however, Berezin's book is well worth reading. It 
represents a significant contribution to our understanding of the Front National phenomenon in France that has fascinated so many scholars. 